\title{
KAJIAN ESTETIKA RAGAM HIAS TENUN SONGKET JINENGDALEM, BULELENG
}

\author{
I Nyoman Sila ${ }^{1}$ dan I Dewa Ayu Made Budhyani ${ }^{2}$ \\ ${ }^{1} J u r u s a n$ Pendidikan Seni Rupa, FBS Universitas Pendidikan Ganesha, ${ }^{2} J u r u s a n P e n d i d i k a n$ \\ Kesejahteraan Keluarga, FTK Universitas Pendidikan Ganesha \\ e-mail: nyoman.sila99@gmail.com, gek bud@yahoo.com
}

\begin{abstract}
Abstrak
Penelitian ini bertujuan mendeskripsikan tentang (1) komposisi penempatan ragam hias tenun songket desa Jinengdalem, Buleleng, (2) ritme/irama penataan ragam hias tenun songket desa Jinengdalem, Buleleng, (3) keharmonisan tata letak ragam hias tenun songket desa Jinengdalem, Buleleng, (4) keseimbangan penataan ragam hias tenun songket desa Jinengdalem, Buleleng, (5) variasi-varisai ragam hias yang dibuat oleh perajin pada kain tenun songket desa Jinengdalem, Buleleng. Penelitian ini menggunakan pendekatan estetika, dan etnografi. Pengumpulan data dilakukan melalui observasi, wawancara, dokumentasi, fokus group, dan dianalisis secara deskriptif kualitatif. Hasil penelitian menunjukkan (1) Kompisisi penempatan ragam hias objek utama, secara umum ditempatkan secara penuh pada bidang kain, (2) Irama penataan ragam hias ditampilkan melalui pengaturan bentuk motif hias seperti: besar, kecil, tinggi, rendah, panjang, pendek, dan juga dalam pengaturan warna yang berbeda-beda secara berulang-ulang. (3) Keharmonisan penempatan ragam hias tenun songket Jinengdalem, melalui motif-motif hias dan warna-warna yang ditampilkan secara keseluruhan dipandang dari nilai-nilai estetikanya sangat harmonis. Karena disini ada keselarasan dalam penempatan motif hias cukup terpadu, penyusunan warna pada beberapa motif hias dengan warna-warna yang komplementer dan tidak ada yang mengalami pertentangan-pertentangan. (4) Keseimbangan penempatan ragam hias pada tenun songket Jinengdalem terlihat pada keseimbangan simetris. Keseimbangan simetris merupakan pengaturan yang tidak banyak mengambil resiko, karena tidak akan menimbulkan kesan berat sebelah. (5) Penempatan ragam hias pada kain tenun songket dilakukan sesuai dengan motif hias yang dibuat. Karena masing-masing motif hias sudah ada polanya seperti misalnya motif hias tirta nadi, siapapun yang membuat motif hias tersebut polanya pasti sama sesuai pakem sebagai motif hias kain tenun songket Jinengdalem. Variasi yang dilakukan oleh perajin adalah pada pengaturan atau penempatan isian-isian dari motif tersebut. Variasi juga dilakukan pada penempatan objek-objeknya, dan juga pada penempatan hiasan pinggirnya pada kain.
\end{abstract}

Kata-kata kunci: estetika, ragam hias, tenun songket

\begin{abstract}
This study aimed at describing (1) the composition of the places of the decorated styles in the songket woven cloth from the village of Jinengdalem, Buleleng (2) the rhythm in the structure of the decorated styles in the songket (3) the harmony of the places of the decorated styles in the songket, (4) the balance of the structure in the decorated styles, (5) the variations in the decorated styles by an artist. This study used aesthetic approach and ethnography. The data were collected through observation, interview, documentation, focus group discusion and analyzed in a qualitative-descriptive manner. The results showed that (1) the composition of the main object decorative style in general is placed on the cloth area;(2) the rhythm of the structure in the decorated style is shown through the arrangement of shapes of the decorated motif such as: large, small, high, low, long, short, and also in the repetitive arrangement of various colors; (3) the harmony of the places of the decorated styles in the songket woven cloth from the village of Jinengdalem, viewed from in decorated motifs and colors that are shown as a whole from the point of view of aesthetic value is very harmonious. Since here there is a harmony in the places of the decorated style with
\end{abstract}


sufficient integrity, the order of colors on some decorated motifs with complementary colors with none of which undergoing contradictions. (4) the balance in the places of the decorated styles in the songket woven cloth from Jinengdalem is shown in the symmetrical balance. The symmetrical balance is the arrangement with less risk, since it will not make imbalanced impression. (5) the places of the decorated styles on the songket woven cloth is done in accordance with the decorated style that is created. Since every decorated motif has its own pattern, such as for instance, tirta nadi decorated style, anyone who creates the decorated motif will create the same pattern in accordance with the standard as the decorated style in the songket woven cloth from Jinengdalem. The variation done by an artist is on the arrangements or places of the contents of the motifs. The variation is also done on the places of the objects and on the places of the decorations at the edges of the cloth.

Keywords: aesthetics, decorated style, songket woven cloth

\section{PENDAHULUAN}

Pada kain tenun songket yang paling menonjol dapat kita lihat adalah bentuk-bentuk ragam hiasnya. Dari ragam hias tersebut terpancar nilai-nilai keindahan atau estetika yang sangat menarik sebagai karya seni yang berkualitas. Pembuatan ragam hias tersebut dilakukan dengan cara menambahkan benang pakan (horisontal waktu menenun) dengan menggunakan benang emas, benang perak, atau jenis benang berwarna lainnya pada benang lungsi (posisi vertikal) waktu menenun. Bila dilihat cara penambahan benang pakan dengan benang emas, benang perak, atau jenis benang berwarna lainnya kelihatan seperti menyungkit pada saat proses menenun (Nusyirwan, 1982: 9).

Ragam hias tenun songket diciptakan dengan teknik tenunan yang dikenal dengan teknik pakan tambahan (suplementary weft). Cara mengangkat mulut lungsi diatur oleh lidi-lidi. Makin banyak jumlah lidi-lidinya, makin rumit dan kaya dengan ragam hiasnya. Betapa terampilnya penenun songket yang harus mengerjakan ragam hias melalui teknik tenun dengan jumlah lidi-lidi kurang lebih 100 biji tanpa mengalami kesalahan tenun, adalah sesuatu pekerjaan yang sangat terpuji (Yusuf Affendi, 1981: 26).

Ragam hias yang ada pada kain tenun songket merupakan perwujudan keindahan manusia dan alamnya. Terciptanya ragam hias ini dilandasi oleh pengetahuan manusia tentang lingkungannya yang dapat merangsang untuk menciptakan aneka ragam hias. Benda-benda alam yang diterjemahkan ke dalam bentuk-bentuk ragam hias seperti, tumbuh-tumbuhan, binatang, manusia, unsur-unsur alam, nilai-nilai agama dan kepercayaan disarikan ke dalam suatu perwujudan keindahan yang harmonis (Gelebet, 1982, dan Budiastra, 1984).

Berdasarkan hasil penelitian yang telah dilakukan oleh I Ketut Parmada yang berjudul "Songket Desa Jinengdalem, Kecamatan Buleleng, Kabupaten Buleleng, Tahun 1998", bahwa masyarakat desa Jinengdalem, Buleleng, khususnya kaum wanitanya sebagian besar sebagai perajin kain tenun songket yang sudah melakukannya bertahun-tahun secara turuntemurun.

Berkembangnya seni tenun songket di Desa Jinengdalem sangat besar peranannya terhadap keberadaan kain tenun songket yang ada di Kabupaten Buleleng, dan bahkan satu-satunya yang masih berkembang dengan baik sebagai seni kerajinan tenun songket yang memiliki ciri khas sebagai karya kain tenun songket Buleleng. Tentu saja hal ini yang menjadi perbedaan dengan hasil tenun songket yang ada di daerah lain di Bali.

Berdasarkan latar belakang tersebut dapat dirumuskan masalahnya

Bagaimanakah komposisi penempatan ragam hias tenun songket desa 
Jinengdaleng, Buleleng? (2) Bagaimanakah ritme/irama penataan ragam hias tenun songket desa Jinengdalem, Buleleng? (3) Bagaimanakah keharmonisan tata letak ragam hias tenun songket desa Jinengdalem, Buleleng? (4) Bagaimanakah keseimbangan penataan ragam hias tenun songket desa Jinengdalem, Buleleng? (5) Bagaimanakah perajin tenun songket menempatkan variasi-variasi ragam hias pada kait tenun songket desa Jinengdalem, Buleleng?

Estetika adalah ilmu yang mempelajari segala sesuatu yang berkaitan dengan keindahan, mempelajari semua aspek dari apa yang kita sebut keindahan (A.A.M. Djelantik, 1999: 9). Dalam filsafat keindahan "pengalaman estetis" tentang sesuatu mengapa ada objek yang disebut indah. Objek itu dikaji melalui pendekatan yang berdasarkan pada nilai-nilai estetis atau unsur-unsur estetis atau estetika dari objek tersebut ( Mudji Sutrisno, FX., SJ, dan Christ Verhaak SJ, 1993: 13).

Estetika yang terdapat dalam ragam hias berkaitan dengan unsur-unsur yang dapat mendukung nilai-nilai estetika atau keindahan tersebut. Unsur-unsur estetika tersebut meliputi wujud yang menyangkut masalah bentuk dan struktur, keseimbangan; ada keseimbangan simetri dan non simetri, komposisi, gerak atau irama, harmoni menyangkut masalah kesesuaian atau keserasian, dan lain-lain.

Ragam hias atau ornamen berasal dari bahasa Yunani yaitu dari kata "ornare" yang artinya hiasan atau perhiasan (Soepratno, 1987: 11). Ragam hias atau ornamen itu sendiri terdiri dari berbagai jenis motif dan motif-motif itulah yang digunakan sebagai penghias sesuatu yang ingin kita hiasi. Ragam hias atau ornamen dimaksudkan untuk menghias suatu bidang atau benda, sehingga benda tersebut menjadi indah.

Dalam penggunaannya ragam hias atau ornamen tersebut ada yang hanya berupa satu motif saja, dua motif atau lebih, pengulangan motif, kombinasi motif dan ada pula yang "distilasi" atau digayakan. Pada dasarnya jenis ragam hias itu terdiri atas: (1) motif geometris berupa garis lurus, garis patah, garis sejajar, lingkaran dan sebagainya, (2) motif naturalis berupa tumbuh-tumbuhan, binatang, manusia, unsur-unsur alam, dan lain sebagainya, dengan demikian ragam hias lahir menjadi simbol-simbol atau perlambangan tertentu (Budhyani, 2010).

Penempatan suatu ragam hias atau motif hias pada kain tenun songket terdapat pada bidang-bidang tertentu sesuai dengan luas atau besarnya bidang yang akan ditempati. Di dalam Ensiklopedia Indonesia dijelaskan bahwa motif hias menjadi pangkal bagi tema suatu buah kesenian. Sejalan dengan pendapat itu, melalui segi visual bila terdapat suatu goresan sebuah garis lengkung, maka goresan tersebut dapatlah disebut sebagai suatu motif, yaitu motif garis lengkung. Kalau garis lengkung tadi diulangulang secara simetris, maupun non simetris kemudian menjadi sebuah pola, bahkan tidak hanya sebuah saja, tetapi akan bergantung pada kemungkinan kreativitas seseorang di dalam merangkainya. Selanjutnya apabila pola yang telah diperoleh itu diterapkan atau dijadikan suatu hiasan seperti pada seni tenun songket, maka kedudukannya adalah sebagai hiasan pada bangunan tersebut (Gustami Sp., 1980: 7).

Lebih lanjut dalam penempatan sebuah ragam hias yang memiliki posisi simetris dapat menggambarkan suatu keseimbangan yang banyak dilakukan oleh para seniman di masa lampau. Cara penggambaran seperti ini dapat pula dihubungkan cara hidup serba seimbang, hidup rukun bergotongroyong, bahu membahu yang biasa dilakukan masyarakat desa. Maka, dengan kesemuanya itu mencerminkan suatu timbal balik yang sepadan, yang tampaknya sangat mempengaruhi penciptaan-penciptaan karya seninya. Dalam menghasilkan atau mewujudkan ragam hias sebagai pengorganisasian unsur-unsur visual dalam 
seni rupa berupa garis, bidang, warna, tekstur dan lain-lain itu akan memberi warna baru pada produk-produk seni yang lahir, menjadi seimbang merupakan ungkapanungkapan estetik dengan perimbangan yang sempurna.

Pada setiap ragam hias terdapat tiga komponen pokok yaitu adanya suatu tokoh sebagai pokok yang diceritakan, kemudian figuran-figuran sebagai pendukung motif pokok atau berfungsi sebagai latar belakang suatu susunan, dan isian-isian untuk menambah keindahan secara keseluruhan. Motif pokok, kecuali menjadi pusat perhatian dan memegang peranan penting yang kuat dalam suatu susunan, juga merupakan wakil dari apa yang dimaksud oleh penciptanya, merupakan pokok persoalan yang diceritakan. Sedangkan figur-figur itu dimaksudkan sebagai motif-motif penunjang pola pokok untuk mencapai keberhasilan pada tingkat yang bagus atau sebagai pengiring dalam suatu penampilan. Goresan-goresan itu dimaksudkan sebagai kelengkapan dari suatu susunan ragam hias, di samping berfungsi untuk menambah keindahan ragam hias secara keseluruhan (Gustami Sp., 1980: 8-9).

Dari komponen pokok kalau diperhatikan secara umum ragam hias yang berkembang pada prinsipnya ada lima jenis yakni: ragam hias geometris, tumbuhtumbuhan, binatang, manusia, dan unsurunsur alam yang didesain sesuai dengan penempatannya (Seraya, 1980/1981: 1112).

Sesungguhnya suatu ragam hias dapat pula diartikan sebagai suatu "desain" atau "pola" sesuai dengan pengertian umum, dan dalam konteks yang terbatas, mengingat masing-masing istilah itu memiliki pengertiannya dan kegunaan-kegunaan tersendiri (Gustami Sp., 1980:9). Namun demikian dalam lingkup arti kata itu sendiri baik motif, pola ataupun desain yang dalam satu pengertian itu, sesungguhnya lebih dekat dengan apa yang disebut motivasi yang dalam suatu saat merupakan keharusan untuk diwujudkan. Dengan demikian kelahiran ragam hias akan tetap memiliki maknanya yang dalam, merupakan ungkapan-ungkapan idealisasi atau gagasan-gagasan pencipta dari perasaan seni dengan media ragam hias. Tetapi tidaklah dapat dibantah bahwa ungkapanungkapan yang estetik itu mempunyai tujuan-tujuan tertentu dengan berbagai bentuk dan pengulangan pada objek-objek yang fungsional.

\section{METODE}

Penelitian ini adalah penelitian kualitatif, dengan menggunakan pendekatan estetika, dan etnografi. Lokasi penelitian adalah di Desa Jinengdalem, Kecamatan Buleleng, Kabupaten Buleleng. Sumber informan dalam penelitian ini adalah perajin tenun songket Jinengdalem, dan pemerhati seni (ahli dalam bidang seni rupa) yang dipilih secara purposive, untuk mendapatkan data yang berkaitan dengan penelitian. Adapun sumber informannya adalah 5 orang perajin tenun songket, dan satu orang pengamat seni. Pengumpulan data dilaksanakan melalui: (a) observasi, (b) wawancara, (c) dokumentasi, (d) fokus group. Semua data yang diperoleh di lapangan yang menyangkut masalah: komposisi penempatan ragam hias tenun songket Jinengdalem, irama/ritme ragam hias kain tenun songket Jinengdalem, harmoni/keharmonisan penempatan ragam hias kain tenun songket Jinengdalem, keseimbangnan penempatan ragam hias kain tenun songket Jinengdalem, dan variasi penempatan ragam hias tenun songket oleh perajin tenun songket Jinengdalem, Kecamatan Buleleng, Kabupaten Buleleng, dianalisis secara deskriptif kualitatif.

\section{HASIL}

Berdasarkan hasil observasi dan wawancara terhadap perajin tenun songket Jinengdalem, hasil penelitian menunjukkan bahwa perajin tenun songket walaupun mengalami pasang surut dalam memproduksi karyanya, namun sebagai seni 
kerajinan yang menjadi warisan tradisi secara turun-temurun masih tetap berjalan dengan baik. Hal ini dapat dibuktikan melalui jenis-jenis kain tenun songket dan penerapan motif hiasnya yang dihasilkan oleh perajin Jinengdalem sampai saat ini sangat beragam.

Keragaman hasil tenun songket yang dihasilkan oleh perajin tidak hanya beragam pada jenis ragam hiasnya, akan tetapi juga kain tenun songket yang dihasilkan, termasuk juga keanekaragaman warna yang ditampilkan dari tenunan benang emas, benang perak, dan jenis benang berwarna lainnya yang memberikan estetika tersendiri hasil tenun songket Jinengdalem. Tidak dapat dipungkiri pada zaman sekarang ini, bahwa perajin selalu setia memroduksi barang kerajinan karena hanya mengisi waktu luang, akan tetapi semangat kerja selalu tumbuh berkat pesanan dari para konsumen.

Jenis-jenis kerajinan tenun songket yang dihasilkan oleh perajin Desa Jinengdalem adalah: kain/kemben, saput/kampuh, ada juga beberapa jenis yang lainnya seperti selendang, dan taplak meja. Semua jenis produk ini sebagai ciri produksi perajin Jinengdalem. Sebagai karya seni kerajinan yang tradisional alatalat yang digunakan untuk memroduksi masih bersifat tradisional, atau disebut juga alat tenun cagcag. Ketekunan dan keuletan para perajin wanita dalam berkarya/menenun menjadi modal dasar sehingga kualitas barang yang dihasilkan menjadi baik.

Dalam pembuatan motif hias tidak semua penenun bisa mengerjakannya. Berdasarkan hasil observasi dan wawancara secara langsung di lapangan, saat ini ada empat perajin yang menguasai pembuatan motif hias, karena dalam tenun songket untuk membuat motif hias harus dapat menentukan jumlah lidi-lidi yang disusun secara matematis untuk menentukan jenis motif hias tersebut. Melalui hasil observasi yang telah dilakukan, Di Desa Jenengdalem ada kurang lebih 10 jenis motif hias yang dibuat oleh para perajin. Motif-motif hias tersebut antara lain: motif hias cakra kurung, motif hias semangi gunung, motif hias mawar, motif hias burung merak, motif hias mawar jumputan, motif hias pucuk/kembang sepatu, motif hias tambalan, motif hias bulan, motif hias tirta nadi, dan motif hias enjekan siap/cakar ayam.

Penempatan motif-motif hias tersebut tentu saja memiliki ciri masingmasing sesuai dengan nama motif hias tersebut. Dalam penempatan motif-motif hias pada kain tenun songket Jinengdalem memiliki keragaman komposisi, proporsi, harmoni, maupun keseimbangan sesuai cita rasa seni dari perajin. Berikut ditampilkan ragam hias tenun songket Jinengdalem yang

diterapkan pada beberapa jenis kain tenun songket seperti di bawah ini.

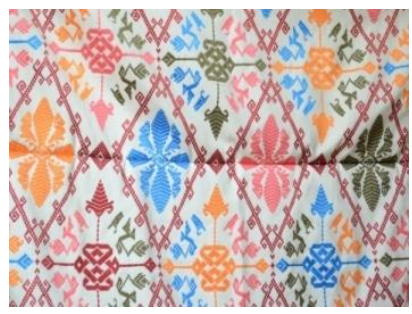

Gb.1. Motif Cakra Kurung

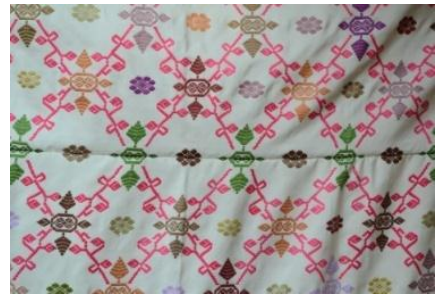

Gb. 2. Motif Semangi Gunung

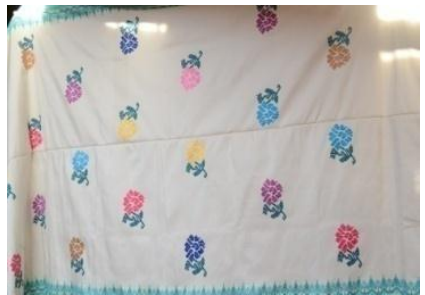

Gb. 3. Motif Mawar 

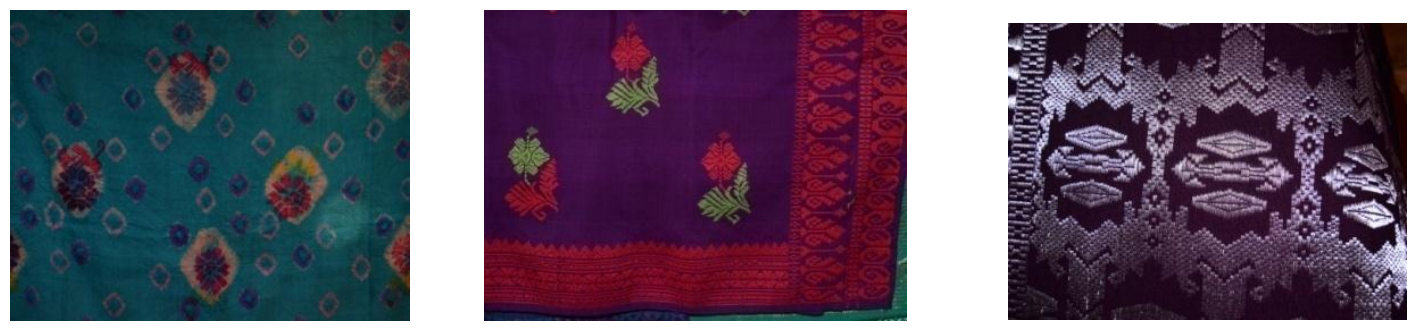

Gb. 4. Motif Mawar Jumputan

Gb. 5. Motif Kembang Sepatu

Gb. 6. Motif Tambalan

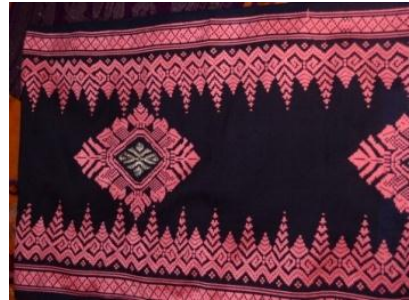

Gb. 7. Motif Bulan

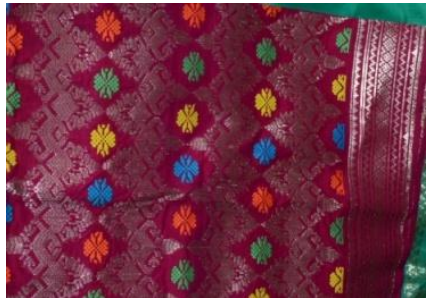

Gb. 8. Motif Tirta Nadi

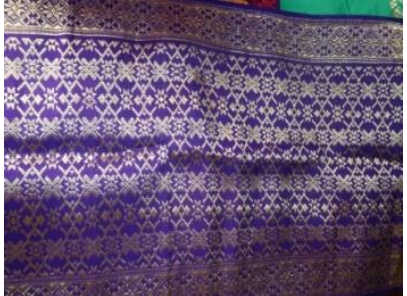

b. 9. Motif Cakar Ayam

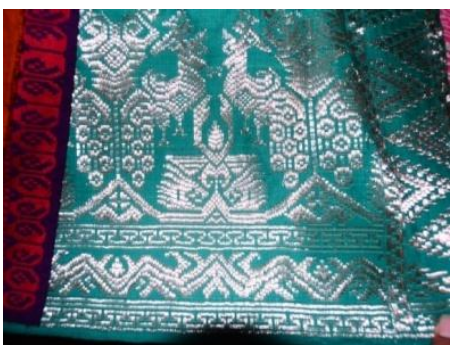

Gb. 10. Motif Burung Merak

\section{PEMBAHASAN}

Berdasarkan hasil penelitian dapat dibahas: (1) Komposisi penempatan ragam hias kain tenun songket Jinengdalem sesuai dengan jenis ragam hias yang diterapkan pada kain tenun songket tersebut. Secara umum tidak hanya satu jenis ragam hias yang ditempatkan, namun ragam hias yang dominan menjadi ragam hias utama, walaupun ada beberapa jenis ragam hias yang menjadi pelengkap atau isian-isian untuk memenuhi bidang kain tenun songket. Komposisi penempatan motif hias: cakra kurung, semangi gunung, tirta nadi dan cakar ayam ditempatkan secara penuh dan motif hiasnya saling bertautan pada bidang kain tenun songket. Komposisi penempatan motif hias: bunga mawar, bunga kembang sepatu, mawar jumputan, tambalan, burung merak, dan bulan penempatannya diatur dengan jarak antara motif satu dengan lainnya sehingga ada sela-sela bidang yang kosong. Secara keseluruhan semua motif hias tersebut diatur sedemikian rupa sehingga memiliki nilai estetis baik dari segi bentuk motif hiasnya maupun jenis warna yang memberi keragaman variasi warna motif kain tenun songket Jinengdalem. Selain komposisi motif utama yang 
ditempatkan pada tengah-tengah bidang kain tenun songket, untuk pengaturan komposisi motif isian atau pelengkap ditempatkan pada bagian pinggiran kain tenun songket. Motif hias tersebut ada yang berbentuk geometris, ada berupa stiliran tumbuh-tumbuhan, maupun binatang. (2) Irama/ritme penataan ragam hias tenun songket Jinengdalem ditampilkan secara berulang-ulang secara teratur. Pengulangan pengaturan motif hias tergantung dari jenis motif hias yang diterapkan. Pengaturan disini dimaksudkan motif-motif yang sama disusun secara berulang-ulang tetapi tidak monoton sehingga secara keseluruhan tampak adanya irama. Irama dapat ditampilkan melalui pengaturan bentuk motif hias seperti: besar, kecil, tinggi, rendah, panjang, pendek, dan juga dalam pengaturan warna yang berbeda-beda secara berulang-ulang. (3) Keharmonisan penempatan ragam hias tenun songket Jinengdalem dapat dilihat pada penyusunan motif hias maupun penampilan warna secara keseluruhan kain tenun songket tersebut. Sesuai dengan pemakaian benang untuk kain tenun, maupun motif-motif hias tenun songket Jinengdalem, serta warnawarna yang ditampilkan secara keseluruhan dipandang dari nilai-nilai estetikanya sangat harmonis. Karena disini ada keselarasan dalam penempatan motif cukup terpadu, penyusunan warna pada beberapa motif dengan warna-warna yang komplementer dan tidak ada yang mengalami pertentangan -pertentangan. (4) Keseimbangan penempatan ragam hias pada tenun songket Jinengdalem terlihat pada keseimbangan simetris. Keseimbangan simetris merupakan pengaturan yang tidak banyak mengambil resiko, karena tidak akan menimbulkan kesan berat sebelah. Secara umum penempatan ragam hias kain tenun songket Jinengdalem adalah simetris. Kesimetrisannya karena penempatan motif hiasnya sama secara berulang-ulang secara penuh pada bidang kain. Seperti pada motif hias cakra kurung, motif hias semangi gunung, motif hias bunga mawar, motif hias mawar jumputan, motif hias tambalan, motif hias tirta nadi, motif hias enjekan siap, dan motif hias burung merak penempatan motifnya menyebar dan tidak ada yang berat sebelah. Pada motif hias bunga pucuk dan motif hias bulan keseimbangan terlihat pada hiasan pokok dan hiasan pinggirnya. Hiasan pinggiran pada bagian atas dan bawah, hiasan pinggir kanan dan kiri dibuat secara simetris, sehingga tidak ada yang berat sebelah. (5) Berdasarkan observasi dan wawancara yang dilakukan terhadap perajin, bahwa penempatan ragam hias pada kain tenun songket dilakukan sesuai dengan motif hias yang dibuat. Karena masngmasing motif hias sudah ada polanya seperti misalnya motif hias tirta nadi siapapun yang embuat motif hias tersebut polanya pasti sama sesuai pakem sebagai motif hias kain tenun songket Jinengdalem. Variasi yang dilakukan oleh perajin adalah pada pengaturan penempatan isian-isian dari motif tersebut. Variasi juga dilakukan pada penempatan objek-objeknya dan juga pada penempatan hiasan pinggirnya.

\section{SIMPULAN}

Berdasarkan hasil dan pembahasan
dapat disimpulkan: (1) Komposisi penempatan ragam hias kain tenun songket Jinengdalem secara umum tidak hanya satu jenis ragam hias yang ditempatkan, namun ragam hias yang dominan menjadi ragam hias utama, dan penempatan ragam hias secara penuh pada bidang kain. (2) Irama/ritme penataan ragam hias tenun songket Jinengdalem ditampilkan secara berulang-ulang secara teratur. Pengulangan pengaturan motif hias tergantung dari jenis motif hias yang diterapkan. Pengaturan disini dimaksudkan motif-motif yang sama disusun secara berulang-ulang tetapi tidak monoton sehingga secara keseluruhan tampak adanya irama. Irama dapat ditampilkan melalui pengaturan bentuk motif hias seperti: besar, kecil, tinggi, rendah, panjang, pendek, dan juga dalam pengaturan warna yang berbeda-beda secara berulang-ulang. (3) Keharmonisan 
penempatan ragam hias tenun songket Jinengdalem dapat dilihat pada penyusunan motif hias maupun penampilan warna secara keseluruhan kain tenun songket tersebut. Sesuai dengan pemakaian benang untuk kain tenun, maupun motif-motif hias tenun songket Jinengdalem, serta warnawarna yang ditampilkan secara keseluruhan dipandang dari nilai-nilai estetikanya sangat harmonis. Karena disini ada keselarasan dalam penempatan motif cukup terpadu, penyusunan warna pada beberapa motif dengan warna-warna yang komplementer dan tidak ada yang mengalami pertentangan -pertentangan. (4) Keseimbangan penempatan ragam hias pada tenun songket Jinengdalem terlihat pada keseimbangan simetris. Keseimbangan simetris merupakan pengaturan yang tidak banyak mengambil resiko, karena tidak akan menimbulkan kesan berat sebelah. Secara umum penempatan ragam hias kain tenun songket Jinengdalem adalah simetris. Kesimetrisannya karena penempatan motif hiasnya sama secara berulang-ulang secara penuh pada bidang kain. (5) Penempatan ragam hias pada kain tenun songket dilakukan sesuai dengan motif hias yang dibuat. Karena masing-masing motif hias sudah ada polanya seperti misalnya motif hias tirta nadi siapapun yang membuat motif hias tersebut polanya pasti sama sesuai pakem sebagai motif hias kain tenun songket Jinengdalem. Variasi yang dilakukan oleh perajin adalah pada pengaturan penempatan isian-isian dari motif tersebut. Variasi juga dilakukan pada penempatan objek-objeknya, dan juga pada penempatan hiasan pinggirnya.

\section{DAFTAR RUJUKAN}

Budhyani. 2010. "Ragam Hias Kain Tenun Songket Bali" (Prosiding) Seminar Nasional Mindset Revolution. Malang: Jurusan Teknologi Industri Fakultas Teknik Universitas Negeri Malang.

Budiastra, Putu. 1984. Ragam Hias Kain dalam Kehidupan Manusia. Denpasar: Dirjen Kebudayaan,
Departemen Pendidikan dan Kebudayaan RI.

Djelantik, A.A.M. 1999. Estetika Sebuah Pengantar. Bandung: Masyarakat Seni Pertunjukan Indonesia.

Dwi Marianto, M. 2002. Seni Kritik Seni. Yogyakarta: Lembaga Penelitian Institut Seni Indonesia Yogyakarta.

Gustami, SP. 1980. Nukilan Seni Ornamen Indonesia. Yogyakarta: STSRI "ASRI" Yogyakarta

Kartiwa, Swati. 1982. Songket Indonesia. Jakarta: Direktorat Jenderal Kebudayaan, Departemen Pendidikan dan Kebudayaan.

Marcia Muelder Eaton. 2010. Persoalanpersoalan Dasar Estetika. Terjemahan Embun Kenyowati Ekosiwi. Jakarta: Salemba Humanika.

Moleong, J. Lexy. 1995. Metodologi Penelitian Kualitatif. Bandung: PT. Remaja Rosdakarya.

Mudji Sutrisno, FX. SJ, dan Christ Verhaak SJ. 1993. Estetika Filsafat Keindahan. Yogyakarta: Penerbit Kanisius.

Nusyirwan, A. 1982. Ragam Hias Songket Minangkabau. Padang: Proyek Pengembangan Permuseuman Sumatra Barat.

Parmada, Ketut. 1998. Tenun Songket Jineng Dalem, Kecamatan Buleleng, Kabupaten Buleleng (Skripsi). Singaraja: Sekolah Tinggi Keguruan dan IImu Pendidikan.

Seraya, I Made. 1981. Wastra Wali Koleksi Museum Bali. Denpasar: Proyek Pengembangan Permuseuman Bali.

Spradley, James P. 1997. Metode Etnografi, Terjm. Misbah Zulfa Elizabeth. Yogyakarta: PT. Tiara Wacana Yogyakarta.

The Liang Gie. 1976. Garis Besar Estetik. Yogyakarta: Karya Yogyakarta.

Yusuf Affendi. 1981. Seni Tenun Silungkang dan Sekitarnya. Jakarta: Proyek Media Kebudayaan, Dirjen Kebudayaan, Departemen Pendidikan dan Kebudayaan. 


\title{
PENGGUNAAN ENGLISH AS MEDIUM OF INSTRUCTIONS (EMI) DAN KONSEKUENSINYA TERHADAP PROSES PEMBELAJARAN DITINJAU DARI PERSEPSI SISWA
}

\author{
Luh Putu Artini \\ Jurusan Pendidikan Bahasa Inggris \\ Universitas Pendidikan Ganesha \\ e-mail: Ipartini undiksha@co.id
}

\begin{abstract}
Abstrak
Penelitian ini bertujuan menjelaskan penggunaan bahasa Inggris sebagai bahasa pengantar (EMI) di kelas, bagaimana persepsi guru dan siswa tentang penggunaan bahasa tersebut dan konsekuensinya terhadap proses pembelajaran. Data dikumpulkan dari empat sekolah menengah atas unggulan di Bali melalui rekaman penggunaan bahasa di kelas, kuesioner persepsi guru dan siswa terhadap penggunaan bahasa Inggris dan wawancara. Data dianalisis secara kualitatif deskriptif. Hasil penelitian menunjukkan adanya komitmen dari guru dan siswa untuk menggunakan bahasa Inggris sebanyak mungkin dalam proses pembelajaran walaupun baik guru maupun siswa memiliki keterbatasan dalam hal penguasaan bahasa asing tersebut. Data persepsi menunjukkan bahwa guru secara umum kurang percaya diri dalam menggunakan bahasa asing tersebut dalam proses pembelajaran. Secara konsisten siswa merasa bahasa Inggris yang digunakan oleh guru dalam mengajar kurang jelas. Sebagai kosekuensinya siswa mengalami kesulitan memahami pelajaran dan pengerjaan tugas-tugas. Penelitian ini memberikan bukti empiris tentang perlunya peninjauan kebijakan tentang pendidikan bilingual dalam konteks pendidikan formal di Indonesia.
\end{abstract}

Kata kunci: English as medium of instructions, konsekuensi, persepsi siswa

\begin{abstract}
This study aims at discussing the use of English as medium of instructions (EMI) in classes, how teachers and students perceive the use of it and what the consequences are to the teaching and learning process. Data were collected from four reputable senior high schools in Bali through recording the classroom language, questionnaires to collect data on teachers' and students' perceptions about the use of English as medium of instructions, and interview. The data were analyzed descriptive qualitatively. The findings indicate commitment of both teachers and students to use as much English as they possibly can despite their limitation in English. From perception data, it can be concluded that teachers were generally lack of confidence to use the foreign language in the process of teaching and learning. Consistently, students perceive teachers' use of English was unclear. The consequence was that students found it hard to understand the lesson and to do the tasks. This research provides empirical evidence for the need to reconsider government policy on bilingual education in public schools in Indonesia.
\end{abstract}

Key words: English as medium of instructions, consequence, students' perceptions 


\section{PENDAHULUAN}

Sejak dimulainya reformasi di bidang pendidikan pada tahun 2002, wacana peningkatan kualitas pendidikan menjadi isu strategis di Indonesia. Salah satu kebijakan pemerintah yang dituangkan melalui UUSPN 20/2003, pasal 50 ayat 3 adalah menyelenggarakan program pendidikan sekolah yang berorientasi internasinal yang mana salah

satu penandanya adalah penggunaan bahasa Inggris sebagai bahasa pengantar atau English as Medium of Instruction, atau selanjutnya disebut EMI. Tujuan dari kebijakan ini adalah mewujudkan manusia Indonesia yang cerdas dan kompetitif secara internasional, yang mampu bersaing dan berkolaborasi secara global (Depdiknas, 2006:4-5).

Penggunaan EMI bisa dikatakan sebagai usaha pembaharuan di bidang pembelajaran yang menargetkan pencapaian dua tujuan sekaligus (Crandall, 1998). Kedua tujuan tersebut adalah: (1) kompetensi pada konten bidang studi (subject competence) dan (2) kompetensi bahasa (language competence). Berbagai upaya telah dilakukan pemerintah dalam mendukung kebijakan sekolah unggulan berorientasi internasional ini. Upaya tersebut lebih menyasar guru, yang meliputi kesempatan meningkatkan kualifikasi, in service training, peningkatan kualitas dan kuantitas sarana dan prasarana pembelajaran serta pembinaan dan pendampingan guru dalam implementasi kurikulum. Dalam kegiatan mengajar yang menggunakan EMI, sekolah memiliki strategi yang berbeda-beda. Sebuah sekolah mungkin memilih strategi pendampingan guru oleh dosen perguruan tinggi, sekolah lain mungkin memilih model team teaching atau pendampingan oleh tenaga ahli baik dari dalam maupun luar negeri. Upaya ini dilakukan untuk menjamin pelaksanaan pembelajaran yang berkualitas dan berorientasi internasional. Trend penggunaan EMI memang sudah mendunia (Uys, dkk., 2007) dan berbagai penelitian tentang dampak penggunaannya sudah dilakukan, tetapi penelitian yang terfokus pada persepsi guru dan siswa serta konsekuensi penggunaan EMI di sekolahsekolah di Bali belum banyak dilakukan orang.

Secara khusus penelitian ini bertujuan untuk: (1) membahas penggunaan EMI di sekolah-sekolah unggulan di Bali, (2) menjelaskan bagaimana persepsi guru dan siswa tentang penggunaan bahasa asing tersebut, serta (3) mendeskripsikan apa konsekwensi penggunaan EMI terhadap proses belajar ditinjau dari persepsi siswa. Dalam konteks penelitian ini, kata persepsi didefinisikan sebagai cara pandang dan pemahaman terhadap sesuatu (orang, situasi atau kejadian) yang didasari oleh pengalaman dan pendapat pribadi (personal opinion) sebagaimana yang dijelaskan oleh Banya \& Cheng (1997). Sementara itu, 'kelas' yang dimaksud dalam penelitian ini adalah kelas-kelas dalam mata pelajaran Matematika dan Sains di SMA unggulan, yaitu SMA yang menjadi pelopor penyelenggara program RSBI sebelumnya. Penelitian ini dilakukan karena adanya fenomena semakin banyaknya sekolah dari semua jenjang, baik negeri maupun swasta yang menggunakan EMI di kelas dewasa ini.

\section{EMI dalam Proses Pembelajaran}

Bahasa pengantar dalam proses pembelajaran di kelas sangatlah penting (Martin, 2003; Saeed \& Jarwar, 2012). Penggunaan bahasa pengantar berhubungan langsung dengan proses dan hasil belajar karena guru sebagai fasilitator pembelajaran memiliki tanggung jawab mengantarkan peserta didik pada pencapaian kompetensi melalui bahasa lisan maupun tulisan yang dipakai pada saat menjelaskan, memberi instruksi dan feedback, mengelola kelas, serta mengevaluasi hasil belajarnya. Bahasa yang digunakan tidak saja harus benar dan sesuai dengan tingkat perkembangan bahasa peserta didik, tetapi juga harus merupakan bahasa yang dipahami dengan 
baik oleh siswa (Baker, 1988). Sejalan dengan ini, Artini (2011) menyatakan bahwa apabila guru menggunakan bahasa di luar jangkauan berbahasa peserta didik, bisa dipastikan akan terjadi masalah dalam pembelajaran. Siswa menjadi kurang mampu menangkap pesan atau memahami informasi yang disampaikan oleh gurunya. Lebih jauh, Coleman (2010) menegaskan bahwa penggunaan bahasa yang kurang dipahami peserta didik sebagai bahasa pengantar dalam pembelajaran di sekolah sebenarnya merupakan penghambat bagi kemajuan belajar siswa.

Dalam era globalisasi sekarang ini, bahasa Inggris sudah menjadi lingua franca dalam kancah pergaulan internasional. Saat ini ada sekitar 479 juta orang penutur asli bahasa Inggris, dan lebih dari 700 juta adalah orang yang bisa berbahasa Inggris sebagai bahasa kedua maupun bahasa asing (Nationmaster, 2010). Angka itu memiliki kecendrungan peningkatan yang tajam mengingat semakin banyaknya sekolah yang memasukkan bahasa Inggris dalam kurikulum mereka. Demikian pentingnya posisi bahasa Inggris sekarang ini sehingga bahasa ini sangat diperlukan dalam berbagai bidang kehidupan seperti misalnya pendidikan, pekerjaan maupun sosial sebagaimana yang tercantum pada kutipan berikut ini.,

"English taking up such an important position in many educational systems around the world, it has become one of the most powerful...(Hoare \& Johnson, 1997)"

Kutipan di atas menekankan bahwa Bahasa Inggris tidak hanya penting tetapi sudah menjadi bahasa yang paling 'kuat' (powerful) dan dipakai dalam sistem pendidikan di seluruh dunia. Akan tetapi penggunaan EMI harus mempertimbangkan kemampuan bahasa Inggris dari guru dan siswa. Berdasarkan pengamatan awal di sekolahsekolah unggulan di Bali ditemukan bahwa baik guru maupun siswa masih dalam tahap belajar bahasa Inggris. Kemampuan berbahasa Inggris yang rendah pada guru bisa diramalkan memiliki konsekwensi negative terhadap hasil belajar sebagaimana yang disampaikan oleh Crandall, (1998:18):

"Learners may fail to understand academic concepts through the language they are still learning because their subject content teachers are incapable of assisting them to do so"

(Pebelajar mungkin akan gagal memahami konsep akademis yang diajarkan dengan bahasa yang sedang mereka pelajari karena guru tidak akan mampu mengajarkan konten sambil membantu mereka belajar bahasa). Pendapat ini mempertegas pentingnya pemilihan bahasa pengantar yang tepat dalam mengajar.

\section{METODE}

Penelitian ini adalah penelitian deskriptif kualitatif yang terfokus pada análisis wacana kelas (classroom discourse analysis), persepsi guru dan siswa terhadap penggunaan EMI dan konsekuensinya terhadap proses pembelajaran. Subjek penelitian adalah 16 orang guru (terdiri dari masing-masing 4 orang guru Matematika, Biologi, Fisika dan Kimia) dan 80 orang siswa (masing-masing 20 orang) dari empat SMA unggulan di Bali.

Ada tiga metode dan instrumen pengumpulan data yang digunakan dalam penelitian ini yaitu: observasi kelas untuk mendapat data tentang penggunaan bahasa Inggris sebagai bahasa pengantar (melalui perekaman audio), penyebaran angket untuk mendapat data tentang persepsi guru dan siswa tentang penggunaan EMI (menggunakan kuesioner), dan wawancara untuk mendapat data persepsi siswa tentang konsekuensi penggunaan bahasa Inggris sebagai bahasa pengantar (dengan menggunakan pedoman wawancara terstruktur).

Analisis data dilakukan secara deskriptif kualitatif dimana penggunaan bahasa disimpulkan dari frekuensi 
berbahasa Inggris yang dihitung dari kekerapan penggunaan ujaran-ujaran lisan bahasa Inggris yang digunakan oleh guru selama proses belajar mengajar di kelas. Persepsi guru dan siswa didapatkan melalui perhitungan prosentase respon mereka terhadap butir-butir kuesioner, sementara konsekuensi penggunaan bahasa Inggris di kelas (EMI) didapat melalui triangulasi angket persepsi siswa an wawancara.

\section{HASIL DAN PEMBAHASAN \\ Penggunaan EMI di kelas Matematika dan Sains

Secara umum guru-guru

Matematika dan Sains dari keempat SMA yang diteliti memiliki persepsi positif tentang penggunaan bahasa Inggris sebagai bahasa pengantar. Mereka menganggap bahwa ada manfaat ganda dari penggunaan bahasa asing tersebut bagi siswa, yaitu belajar bahasa dan sekaligus konten sebagaimana yang dikemukan oleh Crandall (1998). Masing-masing guru menunjukkan keseriusan dalam mengampu proses pembelajaran dengan menggunakan bahasa Inggris sebanyak yang mereka bisa. Hal ini ditunjukkan oleh frekuensi penggunaan bahasa Inggris yang berbeda. Rerata frekuensi penggunaan bahasa di keempat SMA unggulan yang diteliti bisa dirangkum sebagai berikut:

Table 01: Rerata Proporsi Penggunaan Bahasa oleh Guru Matematika dan Sains di empat SMA Unggulan dalam satu kali pertemuan

\begin{tabular}{|l|c|c|c|c|c|}
\hline No. & Guru & $\begin{array}{c}\text { Total jml } \\
\text { ujaran }\end{array}$ & $\begin{array}{c}\text { Jumlah ujaran } \\
(\%) \text { dalam } \\
\text { bahasa Inggris }\end{array}$ & $\begin{array}{c}\text { Jumlah ujaran } \\
(\%) \text { dalam } \\
\text { bahasa } \\
\text { Indonesia }\end{array}$ & $\begin{array}{c}\text { Jumlah ujaran (\%) } \\
\text { kombinasi antara } \\
\text { bahasa Indonesia } \\
\text { dan Inggris }\end{array}$ \\
\hline 1. & Matematika & 508 & $250(49,2 \%)$ & $228(44,9 \%)$ & $30(5,9 \%)$ \\
\hline 2. & Kimia & 718 & $237(32,9 \%)$ & $321(44,7 \%)$ & $161(22,4 \%)$ \\
\hline 3. & Biologi & 716 & $234(33 \%)$ & $387(54 \%)$ & $93(13 \%)$ \\
\hline 4. & Fisika & 850 & $616(72,5 \%)$ & $209(24,6 \%)$ & $25(2,94 \%)$ \\
\hline \multicolumn{2}{r|}{ TOTAL } & $\begin{array}{c}2792 \\
(100 \%)\end{array}$ & $1338(47,9 \%)$ & $1145(41 \%)$ & $309(11 \%)$ \\
\hline
\end{tabular}

Berdasarkan data yang disajikan dalam tabel di atas terlihat bahwa guru Fisika menggunakan bahasa Inggris dengan proporsi tertinggi yaitu $72,5 \%$ dan yang terendah adalah Kimia dan Biologi (33\%). Terlepas dari kualitas bahasa Inggris yang dipakai oleh guru, frekuensi penggunaan yang tinggi menunjukkan upaya yang keras dari guru untuk berbahasa Inggris saat mengajar. Hasil wawancara menunjukkan bahwa guru Matematika dan Sains yang diteliti umumnya tidak merencanakan sebelumnya proporsi target penggunaan bahasa melainkan berusaha untuk menggunakan bahasa Inggris sebanyakbanyaknya. Guru Fisika mungkin memiliki rasa percaya diri yang tinggi dalam menggunakan bahasa Inggris sebagai bahasa pengantar sehingga mereka sanggup berbahasa Inggris secara dominan pada kegiatan pembelajaran di kelas. Sementara itu guru Kimia dan Biologi menyatakan bahwa mereka tidak yakin bisa berbahasa Inggris dengan baik sehingga tidak mengherankan kalau mereka tidak banyak menggunakan bahasa Inggris dalam mengajar.

Tabel di atas juga menunjukkan bahwa, hampir sama dengan guru Biologi dan Kimia, guru Matematika tidak banyak berbicara dalam bahasa Inggris. Dari empat kelas yang direkam, jumlah ujaran yang dihasilkan oleh empat guru Matematika di empat sekolah hanya 508. Jadi rata-rata seorang guru matematika berbicara 127 ujaran selama $2 \times 45$ menit. Dengan kata lain 
guru lebih banyak mengalokasikan waktu bagi siswanya untuk mengerjakan tugas. Sementara itu satu orang guru Fisika menghasilkan 212,5 ujaran selama 2 jam pelajaran dimana 159,4 di antaranya dengan bahasa Inggris.

\section{Persepsi Guru tentang Kemampuan Berbahasa Inggris}

Hasil analisis kuesioner persepsi 16 guru yang diteliti menunjukkan bahwa 50\% guru merasa memiliki kemampuan dan kepercayaan diri yang cukup dalam menggunakan EMI dan sebagian lainnya merasa tidak yakin jika mereka selalu bisa menggunakan bahasa Inggris untuk mengajar. Prosentase seperti ini juga muncul pada pernyataan yang berhubungan dengan dampak kemampuan berbahasa mereka terhadap pemahaman siswa. Hanya separuh guru merasa yakin bahwa siswa bisa memahami penjelasan mereka yang menggunakan bahasa Inggris saat mengajar.

Data tentang persepsi guru tersebut mengisyaratkan bahwa setelah melaksanakan pembelajaran dengan bahasa Inggris selama bertahun-tahun, masih banyak guru yang belum merasa yakin dengan kemampuan bahasa Inggrisnya. Hasil analisis data menunjukkan $75 \%$ dari guru Matematika dan Sains merasa tidak yakin bahwa siswa mereka tidak akan menemukan kesulitan dalam memahami penjelasan dalam bahasa Inggris. Selanjutnya, semua guru merasa tidak yakin jika mereka mampu melafalkan kata-kata bahasa Inggris dengan baik. Ini berarti guru menyadari bahwa meskipun mereka menggunakan bahasa Inggris saat mengajar, sesungguhnya mereka belum percaya diri dengan ucapan mereka dalam berbahasa Inggris.

Di balik ketidakyakinan para guru terhadap kemampuan berbahasa Inggris, semua guru menyatakan bahwa mereka menggunakan strategi khusus untuk mengatasi keterbatasan yang mereka miliki dalam menggunakan bahasa Inggris. Pada saat tiba-tiba tidak tahu suatu kata dalam bahasa Inggris, guru menggunakan strategi yang bervariasi, misalnya: (1) mengganti kata-kata bahasa Inggris yang mereka tidak ketahui dengan bahasa Indonesia, (2) meminta tolong kepada siswanya, (3) berbicara pelan dan mengulangi apa yang dikatakan, serta (4) mencari kata yang tidak diketahui di kamus. $75 \%$ guru menyatakan bahwa mereka melakukan upaya memotivasi siswa untuk meningkatkan bahasa Inggrisnya disamping memotivasi diri sendiri untuk berani menggunakan bahasa Inggris untuk mengajar. Guru merasa yakin bahwa keberanian ini berdampak terhadap motivasi peserta didik untuk mengembangkan kemampuan menggunakan bahasa asing tersebut.

\section{Persepsi Siswa tentang Bahasa Inggris sebagai bahasa Pengantar}

Analisis terhadap hasil kuesioner yang dibagikan kepada 80 siswa di kelas Matematika dan Sains di empat SMA unggulan menghasilkan temuan berupa persepsi mereka tentang penggunaan bahasa Inggris sebagaimana yang ditampilkan pada tabel berikut. 
Tabel 02: Persepsi Siswa terhadap Penggunaan EMI

\begin{tabular}{|c|c|c|c|c|c|}
\hline NO. & Indikator & \multicolumn{4}{|c|}{ Respon siswa (\%) } \\
\hline 1 & $\begin{array}{l}\text { Perasaan pada saat guru } \\
\text { mengajar menggunakan EMI }\end{array}$ & $\begin{array}{l}\text { Sangat } \\
\text { senang } \\
(6.76 \%)\end{array}$ & $\begin{array}{l}\text { Senang } \\
(27.40 \%)\end{array}$ & $\begin{array}{l}\text { Biasa saja } \\
(53.42 \%)\end{array}$ & $\begin{array}{c}\text { Tidak } \\
\text { senang } \\
(13.67 \%)\end{array}$ \\
\hline 2 & $\begin{array}{l}\text { Kemampuan dalam mengikuti } \\
\text { pelajaran dengan } \\
\text { menggunakan EMI }\end{array}$ & $\begin{array}{l}\text { Sangat } \\
\text { mampu } \\
(6.85 \%)\end{array}$ & $\begin{array}{c}\text { Mampu } \\
(65.75 \%)\end{array}$ & $\begin{array}{r}\text { Kurang } \\
\text { mampu } \\
(26.03 \%)\end{array}$ & $\begin{array}{c}\text { Tidak } \\
\text { mampu } \\
(1.37 \%)\end{array}$ \\
\hline 3 & $\begin{array}{l}\text { Kesan tentang penggunaan } \\
\text { EMI oleh guru }\end{array}$ & $\begin{array}{r}\text { Sangat } \\
\text { menarik } \\
(10.96 \%)\end{array}$ & $\begin{array}{c}\text { Menarik } \\
(64.36 \%)\end{array}$ & $\begin{array}{c}\text { Kurang } \\
\text { menarik } \\
(13.67 \%)\end{array}$ & $\begin{array}{c}\text { Tidak } \\
\text { menarik } \\
(10.96 \%)\end{array}$ \\
\hline 4 & $\begin{array}{l}\text { Kejelasan perkataan atau } \\
\text { penjelasan guru ketika } \\
\text { menggunakan EMI }\end{array}$ & $\begin{array}{l}\text { Sangat } \\
\text { jelas } \\
(1.37 \%)\end{array}$ & $\begin{array}{c}\text { Jelas } \\
(24.46 \%)\end{array}$ & $\begin{array}{l}\text { Kurang } \\
\text { jelas } \\
(49.36 \%)\end{array}$ & $\begin{array}{c}\text { Tidak } \\
\text { jelas } \\
(26.03 \%)\end{array}$ \\
\hline 5 & $\begin{array}{l}\text { Kesulitan dalam memahami } \\
\text { penjelasan guru ketika } \\
\text { menggunakan EMI }\end{array}$ & $\begin{array}{c}\text { Sangat } \\
\text { sering } \\
(15.07 \%)\end{array}$ & $\begin{array}{c}\text { Sering } \\
(24.66 \%)\end{array}$ & $\begin{array}{c}\text { Kadang- } \\
\text { kadang } \\
(57.53 \%)\end{array}$ & $\begin{array}{c}\text { Tidak } \\
\text { pernah } \\
(2.74 \%)\end{array}$ \\
\hline
\end{tabular}

Sebagaimana yang terlihat pada tabel 03 di atas, hanya sekitar 34\% dari siswa yang diteliti merasa senang dengan digunakannya EMI di kelas. Walaupun sebagian besar siswa menganggap bahwa pembelajaran dengan EMI itu menarik, tetapi $75,39 \%$ siswa mengatakan bahwa penjelasan guru kurang atau tidak jelas. Selain itu sekitar 53\% siswa beranggapan bahwa penggunaan bahasa Inggris tidak ada istimewanya (biasa saja).

\section{Konsekuensi Penggunaan EMI terhadap Proses Pembelajaran}

Kuesioner persepsi siswa dan wawancara mengantarkan pada temuan tentang beberapa konsekuensi penggunaan bahasa Inggris sebagai bahasa pengantar. Pertama, dari persepsi siswa bahwa pembelajaran dengan bahasa Inggris tidak ada istimewanya (biasa saja) menunjukkan bahwa siswa kurang tertantang untuk bersemangat dalam belajar di kelas. Padahal sesungguhnya semangat (enthusiasm) dalam belajar sangat penting untuk menciptakan suasana belajar yang kondusif yang berdampak terhadap peningkatan kualitas belajar. Untuk itu, menurut Brewster, dkk. (2007), guru harus bekerja keras untuk memelihara perasaan bersemangat (feeling of enthusiasm) peserta didik dalam rangka mengoptimalisasi kualitas dan hasil belajar. Data menunjukkan bahwa di mata siswa, guru tidak memiliki kemampuan berbahasa Inggris yang cukup memadai untuk menyelenggarakan proses belajar dan mengajar dalam bahasa Inggris. Hal ini sesuai dengan hasil penelitian Pena Pendidikan 2009 dalam Sultan, dkk. (2012) yang menemukan bahwa profisiensi berbahasa guru Matematika dan Sains di Indonesia sangat rendah yang dibuktikan dengan hasil TOEFL yang sangat rendah. Sundusiyah (2010) dan Kustulasari (2009) seperti yang dikutip dalam Sultan, dkk. (2012) juga menemukan bahwa sebagian terbesar guru-guru RSBI yang diteliti memiliki kemampuan berbahasa Inggris yang rendah. Jadi bisa dibayangkan pengalaman belajar seperti apa yang dialami siswa apabila penggunaan EMI di kelas kurang efektif. Siswa kemungkinan mengalami kebingungan dalam memahami konten pembelajaran akibat tidak jelasnya bahasa yang digunakan oleh guru.

Dari data respon siswa terhadap pertanyaan "Apakah kamu mengalami 
kesulitan dalam memahami penjelasan guru menggunakan EMI?", 57,53\% mengatakan bahwa mereka kadang-kadang sulit memahami. Kata 'kadang-kadang' memang relatif, tetapi yang jelas siswa tidak selalu bisa memahami penjelasan guru dengan mudah.

Dari semua temuan tentang penggunaan EMI oleh guru Matematika dan Sains, ada satu poin positif dimana siswa merasa tertantang untuk lebih meningkatkan bahasa Inggrisnya. Ini bisa dilihat dari temuan bahwa $79,55 \%$ siswa merasa penggunaan bahasa Inggris di kelas berpengaruh terhadap penguasaan bahasa Inggris mereka secara umum. Hal ini sudah tentu perlu penelitian lebih lanjut, pada ketrampilan berbahasa yang mana peningkatan penguasaan berbahasa Inggris tersebut paling dominan. Menurut Arkoudis (2003), guru memiliki peran utama dalam peningkatan berbahasa siswanya, yang meliputi pengetahuan dan ketrampilan mendengar, berbicara, menulis dan membaca. Demikian juga perlu diteliti apakah peningkatan penguasaan bahasa Inggris terjadi akibat bahasa yang digunakan oleh guru atau karena motivasi berprestasi mereka memang tinggi sehingga mereka berusaha belajar sendiri untuk meningkatkan kemampuan berbahasa Inggris tersebut.

Temuan di atas menyisakan beberapa pertanyaan besar tentang penggunaan EMI di SMA unggulan. Biasanya siswa di sekolah unggulan dipilih secara ketat dengan kriteria yang jelas. Salah satu kriteria adalah kemampuan berbahasa Inggris dan prestasi belajar Matematika dan Sains. Jadi dengan demikian, sebelum memulai pendidikan di SMA unggulan, siswa sebenarnya telah memiliki 'bekal' yang cukup untuk mengikuti kelas yang menggunakan EMI karena telah dinilai layak untuk diterima berdasarkan nilai background knowledge serta bahasa Inggris yang semestinya sudah di atas rata-rata. Pada kenyataannya, siswa menghadapi masalah dalam proses pembelajaran yang menggunakan EMI. Masalah terutama diakibatkan oleh keterbatasan kemampuan guru dalam menggunakan bahasa Inggris, apalagi untuk mengajar mata pelajaran yang memang tergolong sulit dari segi konsep.Analisis terhadap kuesioner yang ditriangulasi dengan data wawancara mengasilkan data sebagai berikut.

Tabel 03. Persepsi Siswa terhadap penggunaan EMI dan konsekuensinya terhadap strategi belajar

\begin{tabular}{|c|c|c|c|}
\hline No & Pernyataan & Masalah & Konsekuensi \\
\hline 1 & $\begin{array}{l}\text { Pilihan kata \& } \\
\text { kalimat bahasa } \\
\text { Inggris yang } \\
\text { digunakan oleh } \\
\text { guru }\end{array}$ & $\begin{array}{l}36,7 \% \text { siswa } \\
\text { merasa pilihan } \\
\text { kata dan kalimat } \\
\text { guru sulit } \\
\text { dimengerti dan } \\
50,68 \% \text { merasa } \\
\text { biasa saja }\end{array}$ & $\begin{array}{l}\text { Bahasa Inggris yang dipergunakan guru bagi } \\
\text { sebagian besar siswa kurang bisa dimengerti } \\
\text { sebagai akibat dari pilihan kata maupun } \\
\text { konstruksi kalimat yang dipilih atau karena } \\
\text { ucapan yang kurang jelas. Sebagai } \\
\text { konsekuensinya, siswa merasa perlu untuk } \\
\text { mereview pelajaran di kelas dengan cara } \\
\text { membaca kembali (belajar sendiri) atau } \\
\text { berkelompok, mengikuti les tambahan dari } \\
\text { guru atau dari bimbingan belajar. }\end{array}$ \\
\hline 2 & $\begin{array}{l}\text { Kesulitan dalam } \\
\text { mengerjakan soal } \\
\text { atau tugas yang } \\
\text { menggunakan } \\
\text { bahasa Inggris }\end{array}$ & $\begin{array}{l}28,77 \% \text { siswa } \\
\text { merasa sering } \\
\text { mengalami } \\
\text { kesulitan } \\
\text { mengerjakan }\end{array}$ & $\begin{array}{l}\text { Kesulitan mengerjakan tugas-tugas yang } \\
\text { harus dikerjakan di dalam kelas maupun } \\
\text { sebagai pekerjaan rumah dialami siswa } \\
\text { karena guru kurang mampu menjelaskan } \\
\text { maksud dari tugas tersebut atau apa yang }\end{array}$ \\
\hline
\end{tabular}




\begin{tabular}{|c|c|c|c|}
\hline & & $\begin{array}{l}\text { tugas dalam } \\
\text { bahasa inggris } \\
\text { dan } 63 \% \text { merasa } \\
\text { kadang-kadang } \\
\text { sulit. }\end{array}$ & $\begin{array}{l}\text { diharapkan oleh guru dari sebuah tugas. } \\
\text { Walaupun kesulitan semacam ini tidak selalu } \\
\text { terjadi, tetapi menyebabkan kebingungan } \\
\text { siswa pada saat itu terjadi. Konsekuensinya } \\
\text { adalah siswa bertanya kepada temannya } \\
\text { atau mereka mengerjakan tugas sesuai } \\
\text { dengan interpretasinya. Siswa lebih } \\
\text { berorientasi pada penyelesaian tugas dari } \\
\text { pada kualitas tugas. }\end{array}$ \\
\hline 3 & $\begin{array}{l}\text { Komunikasi } \\
\text { antara guru dan } \\
\text { siswa ketika } \\
\text { kegiatan belajar } \\
\text { mengajar } \\
\text { berlangsung }\end{array}$ & $\begin{array}{l}42,47 \% \text { siswa } \\
\text { merasa } \\
\text { komunikasi } \\
\text { dengan bahasa } \\
\text { Inggris di kelas } \\
\text { lancar dan } 38 \% \\
\text { mengatakan } \\
\text { kurang lancar }\end{array}$ & $\begin{array}{l}\text { Siswa memiliki persepsi yg berimbang } \\
\text { tentang apakah komunikasi antara guru dan } \\
\text { siswa lancar atau tidak. Ini bisa dipahami } \\
\text { karena ada kemungkinan siswa memiliki } \\
\text { definisi 'lancar' yang berbeda. Bagi sebagian } \\
\text { siswa lancar berarti guru bisa berbicara } \\
\text { tanpa keraguan, dengan kecepatan normal } \\
\text { seperti saat orang berbicara dalam konteks } \\
\text { sehari-hari. Sementara itu sebagian siswa } \\
\text { menganggap kelancaran harus disertai } \\
\text { dengan kejelasan makna yang disampaikan } \\
\text { yang diimbangi dengan respon dari siswa. } \\
\text { Jadi, lancar atau tidaknya komunikasi di } \\
\text { kelas ditentukan oleh komunikasi antara guru } \\
\text { dan siswa dan juga antara siswa dan guru. } \\
\text { Konsekuensi dari kurang lancarnya } \\
\text { komunikasi antara kedua belah pihak adalah } \\
\text { siswa lebih memilih untuk bertanya kepada } \\
\text { temannya dari pada bertanya pada guru. } \\
\text { Kadang-kadang siswa harus } \\
\text { menginterpretasikan makna atau maksud } \\
\text { guru ketika menjelaskan maupun penugasan } \\
\text { karena mereka enggan untuk bertanya atau } \\
\text { meminta penjelasan kembali dari guru. }\end{array}$ \\
\hline 4 & $\begin{array}{l}\text { Kemampuan } \\
\text { merespon } \\
\text { instruksi guru } \\
\text { dalam bahasa } \\
\text { Inggris }\end{array}$ & $\begin{array}{l}64,38 \% \text { siswa } \\
\text { merasa mampu } \\
\text { merespon } \\
\text { instruksi guru } \\
\text { dalam bahasa } \\
\text { Inggris dan } 33 \% \\
\text { merasa kurang } \\
\text { mampu. }\end{array}$ & $\begin{array}{l}\text { Sebagian besar siswa merasa mampu } \\
\text { merespon instruksi guru dalam bahasa } \\
\text { Inggris. Instruksi yang dimaksud adalah } \\
\text { perintah atau suruhan dengan bahasa } \\
\text { Inggris seperti misalnya: "Who can answer } \\
\text { question 1? Who have animal at home?" } \\
\text { Pertanyaan-pertanyaan seperti ini adalah } \\
\text { bahasa kelas (classroom language) yang } \\
\text { terjadi secara rutin di kelas sehingga siswa } \\
\text { sebenarnya tidak memiliki kesulitan untuk } \\
\text { memahami maupun merespon dengan } \\
\text { bahasa Inggris sederhana. Banyak siswa } \\
\text { yang menyatakan kurang mampu merespon } \\
\text { karena ada interpretasi yang berbeda } \\
\text { tentang apa yang dimaksud dengan instruksi } \\
\text { dalam bahasa Inggris. Mereka menganggap }\end{array}$ \\
\hline
\end{tabular}




\begin{tabular}{|c|c|c|c|}
\hline & & & $\begin{array}{l}\text { semua pertanyaan yang diajukan guru dan } \\
\text { harus dijawab dalam bahasa Inggris sebagai } \\
\text { instruksi sehingga banyak yang mengatakan } \\
\text { kurang mampu menjawab instruksi guru } \\
\text { dalam bahasa Inggris. Kosekuensinya } \\
\text { adalah siswa yang merasa kurang mampu } \\
\text { menjadi kurang aktif dalam kegiatan di kelas. } \\
\text { Mereka berusaha agar tidak ditunjuk oleh } \\
\text { guru untuk menjawab pertanyaan. }\end{array}$ \\
\hline 5 & $\begin{array}{l}\text { Pengaruh } \\
\text { penggunaan EMI } \\
\text { terhadap } \\
\text { penguasaan bhs } \\
\text { Inggris }\end{array}$ & $\begin{array}{l}79,55 \% \text { siswa } \\
\text { merasa } \\
\text { penggunaan EMI } \\
\text { berpengaruh } \\
\text { terhadap } \\
\text { kemampuan } \\
\text { berbahasa Inggris } \\
\text { dan } 21 \% \text { merasa } \\
\text { kurang } \\
\text { berpengaruh }\end{array}$ & $\begin{array}{l}\text { Bagi sebagian besar siswa, penggunaan } \\
\text { bahasa Inggris sebagai bahasa pengantar } \\
\text { berpengaruh terhadap kemampuan } \\
\text { berbahasa Inggris mereka. Ketidakpahaman } \\
\text { mereka membuat mereka mempelajari } \\
\text { sendiri materi yang ditulis dalam dua bahasa } \\
\text { (bilingual) sehingga secara tidak langsung } \\
\text { mereka juga mempelajari bahasa Inggris } \\
\text { yang digunakan. Sebagian kecil siswa } \\
\text { menganggap bahwa bahasa Inggris sebagai } \\
\text { bahasa pengantar tidak berpengaruh pada } \\
\text { bahasa Inggris mereka. Hal ini diakibatkan } \\
\text { oleh monotonnya bahasa kelas yang } \\
\text { digunakan oleh guru sehingga tidak ada hal } \\
\text { baru yang mereka rasakan dari segi } \\
\text { penggunaan Inggris. } \\
\text { Konsekuensinya adalah siswa menjadi } \\
\text { kurang bersemangat dalam proses } \\
\text { pembelajaran. }\end{array}$ \\
\hline
\end{tabular}

Data di atas menunjukkan bahwa ada keterkaitan antara persepsi siswa tentang penggunaan EMI dengan proses pembelajaran di kelas. Sebagai contoh, berdasarkan hasil wawancara terungkap bahwa siswa selalu berusaha untuk mempelajari kembali materi yang mereka dapat di kelas di rumah. Hal ini berhubungan dengan kurang jelasnya pembelajaran di kelas sebagai akibat dari kurang bagusnya bahasa Inggris guru untuk mengajar. Jadi ketidakjelasan bahasa guru dalam mengajar memiliki konsekuensi kurang aktifnya siswa di dalam kelas karena mereka lebih memilih untuk mengulangi belajar di rumah, baik dengan membaca sendiri maupun ikut bimbingan belajar ataupun les privat.

Pada saat penugasan di dalam kelas, penjelasan guru juga kadang-kadang tidak jelas. Pada saat hal ini terjadi, siswa memilih untuk bertanya kepada teman sekelasnya dari pada bertanya kepada guru. Hal ini juga berdampak pada proses pembelajaran dimana siswa mengerjakan tugas berdasarkan interpretasi mereka terhadap task requirement atau tagihan yang diminta guru. Pada akhirnya siswa lebih mengutamakan penyelesaian tugas daripada belajar dari tugas. Selain itu pola interaksi yang dominan adalah interaksi guru-siswa dimana frekuensi guru berbicara kepada siswa jauh lebih tinggi daripada frekuensi siswa berbicara kepada guru. Hal ini diakibatkan oleh kendala bahasa baik dari pihak guru maupun siswa. Jadi proses pembelajaran di kelas berjalan secara klasikal dimana guru memegang peran dominan (teacher-centered learning) 
Hasil penelitian ini berujung pada beberapa pertanyaan besar yaitu, (1) Apakah prestasi belajar siswa sekolah unggulan diakibatkan oleh kemampuan guru dalam mengajar dengan menggunakan EMI atau memang karena motivasi siswa untuk belajar memang tinggi?, (2) Apakah peningkatan kemampuan berbahasa Inggris siswa di sekolah unggulan memang merupakan dampak langsung dari penggunaan bahasa Inggris oleh guru di kelas atau merupakan dampak tidak langsung karena siswa berusaha belajar sendiri di rumah sebagai akibat kurang jelasnya penjelasan guru?

Sesungguhnya apabila kemampuan berbahasa Inggris siswa dan guru memadai dalam proses pembelajaran, bisa diharapkan prestasi belajar dan kemampuan berbahasa Inggris siswa akan meningkat (Bostwick, 2005). Bahkan menurut SeikkulaLeino (2007), penggunaan bahasa Inggris sebagai bahasa pengantar tidak akan mengganggu penggunaan bahasa pertama (Bahasa Indonesia) siswa. Ini disebabkan oleh adanya fenomena diglossia dimana siswa secara tidak sadar membangun kebiasaan menggunakan dua bahasa dalam situasi yang berbeda yaitu: menggunakan bahasa pertama (bahasa Indonesia) dalam kehidupan sehari-hari dan bahasa Inggris dalam suasana akademis di sekolah. Sayangnya penelitian ini menunjukkan lemahnya bahasa Inggris guru dan siswa sehingga besar kemungkinan pencapaian tujuan yaitu peningkatan pencapaian hasil belajar konten dan bahasa Inggris sulit untuk tercapai.

Secara singkat penelitian ini memberi gambaran tentang penggunaan bahasa Inggris sebagai bahasa pengantar (EMI) dan konsekuensi penggunaan bahasa asing tersebut terhadap proses pembelajaran ditinjau dari persepsi siswa. Dari respon guru terhadap kuesioner persepsi bisa dirangkum beberapa hal sebagai berikut:
(1) Walaupun menyadari
sebagian besar guru kekurangmampuan

menggunakan bahasa Inggris sebagai bahasa pengantar di kelas, mereka menunjukkan persepsi positif terhadap dampak penggunaan bahasa tersebut terhadap peningkatan pencapaian belajar dan kemampuan berbahasa Inggris siswa. Pendapat ini dipengaruhi oleh pemahaman guru tentang tujuan yang telah dicanangkan oleh pemerintah dalam UUSPN 20/2003, pasal 50 ayat 3 tentang Rintisan Sekolah Berstandar Internasional (RSBI). Hasil review pelaksanaan $\mathrm{RSBI}$ yang mengikuti kurikulum pendidikan bilingual telah dianggap telah gagal (The Jakarta Post, January 09, 2013). Penelitian ini, yang dilakukan sebelum keputusan Mahkamah Institusi tentang penghapusa RSBI dilakukan, telah menunjukkan bahwa sebagian terbesar guru (75\%) tidak yakin kalau siswa mereka tidak akan mengalami kesulitan dalam memahami pembelajaran yang mereka laksanakan dengan bahasa Inggris. Dengan kata lain, mereka sudah bisa meramalkan bahwa siswa kemungkinan besar akan mengalami kesulitan dalam memahami penjelasan mereka yang menggunakan bahasa Inggris. Gambaran persepsi guru seperti ini menunjukkan bahwa penggunaan bahasa Inggris sebagai bahasa pengantar berangkat dari ketidakyakinan guru tentang efektifitas pembelajaran karena mereka merasa kurang percaya diri dengan kemampuan berbahasa Inggris mereka. Hal ini bisa dipahami karena dari riwayat pendidikan para guru Matematika dan Sains, mereka tidak memiliki latar belakang bahasa Inggris yang memadai untuk menyelenggarakan pembelajaran dalam bahasa asing tersebut.

(2) Frekuensi penggunaan bahasa Inggris sebagai bahasa pengantar bervariasi tergantung dari jenis mata pelajaran dan guru yang mengampu mata pelajaran tersebut. Dalam mata pelajaran Matematika misalnya, proporsi kelihatan berimbang antara penggunaan bahasa Inggris dan Bahasa Indonesia. Namun demikian, pada mata pelajaran Fisika, bahasa Inggris digunakan dengan frekuensi yang jauh lebih 
tinggi dari penggunaan bahasa Indonesia. Temuan ini menunjukkan bahwa setiap guru berusaha menggunakan bahasa Inggris semampunya tanpa mempertimbangkan latar belakang teori pembelajaran bilingual yang sesuai dengan tujuan atau target pembelajaran. Padahal penggunaan bahasa pengantar yang tidak jelas dapat berakibat fatal terhadap hasil belajar siswa (lihat Crandall 1998:18 di atas).

(3) Berdasarkan analisis data persepsi siswa ditemukan bahwa efektifitas penggunaan bahasa Inggris sebagai bahasa pengantar dalam pembelajaran Matematika dan Sains di SMA unggulan di Bali bisa dikategorikan kurang efektif. Temuan ini disimpulkan dari persepsi siswa tentang kejelasan bahasa Inggris yang digunakan guru untuk mengajar yang dinilai masih kurang yang berpotensi menyebabkan kebingungan bagi siswa dalam pemahaman materi. Selain itu siswa mengalami kesulitan dalam mengerjakan tugas-tugas yang dirancang oleh guru karena instruksi yang diberikan kurang jelas. Guru memiliki keterbatasan kemampuan mengungkapkan makna dalam bahasa Inggris yang efektif karena terbatasnya katakata bahasa Inggris mereka dan kurangnya kemampuan mengucapkan kata-kata bahasa Inggris dengan tepat. Oleh sebab itu, siswa merasa berkewajiban untuk berusaha sendiri untuk memahami apa yang dimaksud oleh guru dengan cara mempelajari kembali di rumah materi yang mereka dapat di kelas.

\section{SIMPULAN}

Penelitian bertujuan membahas bagaimana penggunaan EMI di kelas,, menjelaskan bagaimana persepsi guru dan siswa terhadap penggunaan EMI tersebut dan mendeskripsikan apa konsekwensi penggunaan EMI terhadap proses pembelajaran ditinjau dari persepsi siswa. Simpulan yang bisa ditarik berdasarkan tujuan tersebut adalah: (1). EMI digunakan sebanyak/sesering mungkin oleh guru dalam pembelajaran. Antara guru satu dan lainnya memiliki frekuensi penggunaan yang berbeda tergantung dari kemampuan berbahasa Inggris masing-masing guru. (2). ada 'konsistensi' antara persepsi guru dan siswa dalam hal penggunaan EMI dalam mata pelajaran Matematika dan Sains di empat sekolah unggulan di Bali. Pada saat guru menyatakan bahwa mereka kurang percaya diri dalam berbahasa Inggris, siswa juga merasa bahwa bahasa Inggris guru mereka kurang jelas atau tidak mudah dimengerti. Di satu pihak semua guru percaya akan dampak positif dari penggunaan bahasa Inggris tersebut tetapi di pihak lain hanya sebagian guru yang memiliki keyakinan dan rasa percaya diri bahwa mereka mampu mengajar dengan penggunaan EMI. Rendahnya kemampuan berbahasa guru menyebabkan kebingungan pada siswa karena ketidakjelasan bahasa pengantar, baik dari segi penggunaan kata maupun pengucapannya. Hal ini tentu harus mendapat perhatian yang serius karena sebagaimana yang disebutkan sebelumnya, sebenarnya kualitas bahasa pengantar sangat berpengaruh terhadap hasil belajar siswa (Martin, 2003; Saeed \& Jarwar, 2012). (3) Ada keterkaitan antara persepsi siswa dengan konsekuensi pengunaan EMI. Menurut siswa, keterbatasan kemampuan guru dalam menggunakan bahasa Inggris memiliki konsekuensi terhadap proses pembelajaran di kelas. Siswa menjadi kurang aktif, kurang bersemangat dan memilih untuk bertanya kepada teman dibandingkan bertanya kepada guru. Selain itu siswa memilih untuk mengulang pelajaran di rumah untuk memastikan mereka mengerti dengan materi yang diajarkan di kelas. Pemilihan bahasa kelas oleh guru juga cenderung monoton sehingga sebagai konsekuensinya, siswa merasa bosan dan kurang termotivasi. Demikian juga kurang jelasnya tugas-tugas yang diberikan menyebabkan siswa mengutamakan penyelesaian tugas dari pada kualitas tugas.

\section{SARAN}

Berdasarkan hasil penelitian 
tersebut di atas bisa disarankan beberapa hal sebagai berikut: (1) Untuk bisa memberi sebuah nilai plus terhadap kualitas output sekolah, penggunaan EMI bisa dikatakan sebagai sebuah alternatif tetapi perlu dimulai dengan penyiapan kondisi berupa kemampuan berbahasa Inggris yang baik dari guru dan siswa. (2) Dengan dihapuskannya RSBI sekarang ini, KTSP masih menyediakan ruang bagi sekolah untuk menyelenggarakan kelas khusus yang menggunakan EMI tetapi harus dengan pertimbangan cerdas. Sekolah harus memiliki pemahaman model kelas bilingual yang sesuai dengan konteks sekolah dan menyesuaikan implementasi model tersebut dengan kondisi dan potensi riil sekolah.

\section{DAFTAR PUSTAKA}

Arkoudis, S. 2003. Teaching English as a second language in Science classes:

Incommensurate epistemologies? Language and Education, 17 (hal: 161-174).

Artini, L.P. (2011). Persepsi Guru dan Siswa terhadap Penggunaan Bahasa Inggris di Kelas Bilingual di Sekolah Menengah Atas Berstatus RSBI di Bali. Jurnal IImu Pendidikan Jilid 17 No.4, Februari 2011 (hal. 307-312).

Baker, C. 1988. Key Issue in Bilingualism and Bilingual education, England: Multilingual Matters, Ltd.

Banya, K. and Cheng, M.A. 1997. Beliefs about Foreign Language Learning: $A$ Study of Beliefs of Teachers and Students' Crosscultural setting. (Paper presented at annual meeting of the teachers of English to speakers other languages, Orlando, March 1115, 1997).

Best, W.J. 1993. Research in Education, New Jersay.USA.Brewster, J., G. Ellis dan D. Girard. (2007). The Primary English Teacher Guide. Harlow: Pearson Education Ltd.
Bostwick, M. 2005. 'What is immersion?', in J Cohen, K.T. McAllister, K. Rolstad \& J. MacSwan (eds), ISB4: Proceedings of the International Symposium on Bilingualism, Cascadilla Press, Somerville MA, USA, pp. 1-4.

Coleman, H. 2010. Teaching Learning in Pakistan: The Role of Language in Education. retrieved on 11 Februari 2012.

Crandall, J. 1998. Collaborate and cooperate: Educator education for integrating language and content instruction. Forum, 36:2.

Depdiknas. $2007 . \quad$ Panduan Penyelenggaraan Rintisan SMA Bertaraf Internasional. Jakarta: Direktorat Pembinaan Sekolah Menengah Atas

Depdiknas.2006. Menuju Pembangunan Pendidikan Nasional Jangka Panjang 2025. Jakarta: Direktorat Pembinaan Sekolah Menengah Atas

Dewaele, J.M., Alex Housen \& Li Wei. 2003. (eds) Bilingualism: Beyond Basic Principles. Sydney: Multilingual Matters Ltd.

Kompas.com 2 Juni, 2010. Penelitian RSBI: Bahasa Inggris bisa hambat 'Kemajuan' (http://www.klubguru.com)

Martin, P. (2003). Bilingual Encounters in the Classroom. In Dewaele, J.M., Alex Housen \& Li Wei (eds) Bilingualism: Beyond Basic Principles. Sydney: Multilingual Matters Ltd.

Saeed, A. and Jarwar, A.Q. 2012. Impact of Medium of Instruction on Achievement level of students at Higher Secondary Stage in Hyderabad Region of Sindh. In Interdisciplinary Journal of Contemporary Research in Business. Vol. 4(4). August, 2012.

Sultan, S., H. Borland, dan B. Eckersley. (2012). English Medium Instruction 
(EMI) in Indonesian Public Junior High Secondary School: Student's language use, attitudes/ motivation and foreign language outcomes. In tesol.org.au/files/224_Sultan

Seikkula-Leino, J 2007, 'CLIL learning: Achievement levels and affective factors', Language and Education, vol. 21, no. 4.

Tomlinson, B. (1990). 'Managing change in Indonesian high schools. EnglishTeaching Journal. 44(1), 2537.

UNESCO. (2001). The Reform of Secondary Education in Indonesia during the 1990s: Improving Relevance and Quality through Curriculum Decentralisasion. [On-line].
(2009). Kualitas Bahasa Inggris Guru Sekolah Internasional Rendah. Harian Suara Merdeka On-line, 26 Juni 2009. http//www.suaramerdeka .com

The Jakarta Post. January 09, 2013. Constitutional Court Brings End to Era of RSBI Schools. Available on http://www.thejakartaglobe.com/educa tion/Retrieved on February 17, 2013.

Uys, M., J. van der Walt, R. van der Berg, and S.Botha. (2007). English as Medium of Instruction: a situation analysis. South African Journal of Education. Vol.27 (1) pp. 69-82. 